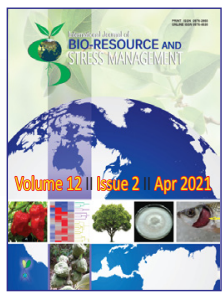

\title{
Pulse Cultivation- A Venture for Food, Nutrition and Livelihood
}

\author{
Arun Kumar Barik
}

Dept. of Agronomy, Palli Siksha Bhavana (Institute of Agriculture), Visva-Bharati, Sriniketan, West Bengal (731 236), India

Open Access

Corresponding Author

Arun Kumar Barik

e-mail: akbarikpsbvb@rediffmail.com

Citation: Barik, 2021. Pulse Cultivation- A Venture for Food, Nutrition and Livelihood. International Journal of Bio-resource and Stress Management 2021, 12(2), i-ii. HTTPS://DOI.ORG/10.23910/1.2021.2192b

Copyright: (c) 2021 Barik. This is an open access article that permits unrestricted use, distribution and reproduction in any medium after the author(s) and source are credited.

Data Availability Statement: Legal restrictions are imposed on the public sharing of raw data. However, authors have full right to transfer or share the data in raw form upon request subject to either meeting the conditions of the original consents and the original research study. Further, access of data needs to meet whether the user complies with the ethical and legal obligations as data controllers to allow for secondary use of the data outside of the original study.

Conflict of interests: The authors have declared that no conflict of interest exists.
Article History

RECEIVED in $24^{\text {th }}$ February 2021 RECEIVED in revised form $28^{\text {th }}$ March 2021 ACCEPTED in final form $29^{\text {th }}$ March 2021

\begin{abstract}
Pulses (food legumes) occupy an important place in Indian agriculture. It provides food, nutrition and Environmental security in bringing income and employment opportunity through various improved technological interventions. Being the largest producer and consumer of pulses, India has to import 3-4 mt of pulses every year to meet its domestic demand. There is an urgent need to increase both productivity and production of pulses to bridge the gap between demand and supply. India needs to provide $39 \mathrm{mt}$ of pulses with the availability of $52 \mathrm{~g}$ capita $^{-1}$ day $^{-1}$ of 1.69 billion people in the projected year of 2050. An additional area of 3-5 mha has to be brought under pulses with a productivity of $1200 \mathrm{~kg}$ ha ${ }^{1}$ against the current productivity of $841 \mathrm{~kg} \mathrm{ha}^{1}$. New research efforts should be attempted to achieve a breakthrough in productivity of pulses. Development of widely adaptable short duration varieties with biotic and abiotic stress resistance, participation of rural youths in producing good quality seeds and establishing village seed hubs, preparation of value added products by women farmers in SHGs, raising minimum support price (MSP) and ensuring procurement are the key factors towards achieving self sufficiency in pulse production. This will increase income, combat malnutrition and provide employment for better livelihood of the resource poor farmers.
\end{abstract}

Keywords: Pulse, productivity, nutrition, livelihood, empowerment

\section{Editorial}

Pulses play an important role in providing food, nutrition and environmental security in a sustainable manner through crop intensification and diversification of cropping systems in Indian agriculture. It has also a significant role in income and employment generation and poverty alleviation. Apart from being an inexpensive source of plant based proteins, vitamins and minerals and a soil health enhancer, residues from legumes are also a valued animal feed.

India is the World's largest producer and consumer of pulses accounting for $34 \%$ of area and $24 \%$ of production followed by Myanmar, Canada, China, Nigeria, Brazil and Australia. Our per capita availability of pulses is $43 \mathrm{~g} \mathrm{capita}^{-1}$ day $^{-1}$ only ( $15 \mathrm{~kg}^{-1}$ capita $^{-1}$ year $^{-1}$ ) against the ICMR recommendation of $52 \mathrm{~g} \mathrm{capita}^{-1} \mathrm{day}^{-1}\left(20 \mathrm{~kg}\right.$ capita $\left.^{-1} \mathrm{year}^{-1}\right)$. To reach self sufficiency at current population level, we need $30 \mathrm{mt}$ of raw pulses against the present production of $24 \mathrm{mt}$. By 2050, India will emerge with a population of 1.69 billion and projected demand of pulses will be $39 \mathrm{mt}$ with an increase of $0.6 \mathrm{mt}_{\text {annum }}{ }^{-1}$ and an additional area of $3.5 \mathrm{mha}$ has to be brought under pulses with a productivity level of $1200 \mathrm{~kg} \mathrm{ha}^{-1}$ against 
the current productivity of $841 \mathrm{~kg} \mathrm{ha}^{1}$ during 2017-18. India imported $11.2 \mathrm{mt}$ of pulses during 2016-17 the value of which was 22160 crores to meet its domestic demand. So there is a dire need to increase both productivity and production of pulses to bridge the gap between demand and supply. In this juncture, various strategies are to be adopted towards increment in production of pulses. There is ample scope for bringing pulses in newer areas such as rice-fallows, lake areas, hill agriculture and in intercropping/mixed cropping for remunerating cropping systems. Rice fields in eastern and central India remain fallow after harvest of rice. Out of total potential pulse area of $6.2 \mathrm{mha}$ in India, $3.5 \mathrm{mha}$ has been targeted for producing pulses in 2025 and $4.75 \mathrm{mha}$ in 2050 in niche areas like inter cropping, catch cropping, rice fallows and khariffallows (after September-October). $68^{\text {th }}$ UN General Assembly, UNO declared 2016, the International Year of Pulses (IYP) for giving impetus to the pulse cultivation Worldwide. FAO was nominated to facilitate implementation of the year of pulses. Of the total net sown area of 141.40 mha, $52 \%$ i.e. $73.20 \mathrm{mha}$ is rainfed and this region supports $80 \%$ of pulse production. So, pulses play a greater role in sustaining the economy of rainfed farming community.

Pulse cultivation needs a boost to increase per capita availability. Pulses face several challenges- farming on marginal lands, low genetic yield potential, poor and unstable yield, huge post harvest losses $(20 \%)$ including milling and storage pests, lack of improved technology and low profitability, dependence on monsoon, lack of irrigation, low input usage and unavailability of location specific short duration varieties. New research efforts should be initiated to achieve a breakthrough in the productivity. Development of shorter duration, widely adaptable and biotic and abiotic stress resistant varieties are necessary in enhancing productivity of pulses. In addition to rice, farmers obtain an extra crop and extra income in mono-cropped agriculture through introduction of pulses in rice fallows with the help of good quality seeds, improved varieties and new technologies. Farmers are unaware about the improved production technologies including varieties. Unavailability of quality seeds is another major issue. Rural youths can be engaged in growing pulse crops in rice-fallows as well as production of good quality seeds, packaging and marketing of seeds, generating more employment for them round the year. Quality seed production programme can be implemented under village based seed enterprise (VBSE) and establishment of village seed hub, so that farmers can use their own good quality seeds in time and need not purchase at higher market price. Capacity building programme are to be implemented through training of men and women farmers, SHGs, field school, field day, farmers' training programme etc.

Value addition may be another source of revenue in generating employment opportunities. Women farmers and Self-Help Groups (SHGs) may be trained for preparation of value-added products from pulses like flours (Besan)of chickpea, fried products (pakora), pulse bori/ dal bori (a conical shape preparation made after grinding the pulse) with the help of aluminium blocks, various types of sweets (viz. Musur Rasbora, Musur Daler Radhaballavi, Musur Khulekhara Bora, Musur Sajne Omlet, Chholar Daler Laddu, Musur Madhupuri, etc.) and Gahana (ornamental) bori. This will help women SHGs for fetching extra income and engage them during leisure time after household work resulting in women empowerment and more employment generation. Poor farmers cannot afford pulses in their everyday diet owing to its high market price where rice-pulse (dal-roti) is the choice of the common people for balance diet. Inclusion of pulses in diet imparts nutritional support to overcome malnutrition of the poor farm families and residue from pulse crops, a rich source of protein, is used as dry fodder to the animals. On the other hand, introduction of pulses in rice fallow, an additional crop, increases the cropping intensity of dry lands with scanty rainfall. It is also necessary to ensure ready marketability of the crop through assured procurement mechanism. Pulse production can help lower the import bill of the country which can be used for other socio economic development.

This holistic approach will boost pulse production towards self sufficiency, provide income to the farmers and ensure nutrition and livelihood improvement to the resource poor farmers of our country. 